\title{
THE RELATION OF PATERNALISTIC LEADERSHIP WITH GLASS CEILING SYNDROME
}

PROBLEMS

OF EDUCATION

IN THE $21^{\text {st }}$ CENTURY

Vol. 79, No. 5, 2021

767

\author{
Pinar Mert \\ Istanbul Sabahattin Zaim University, Turkey \\ E-mail: binarmert@icloud.com
}

\begin{abstract}
Women expose to barriers in their work-life that are not stated clearly. Although these invisible barriers occur in many sectors, they are common in the education sector. So, this study aimed to reveal the relation between the paternalistic leadership displayed by principals in traditional collectivist cultures and the glass ceiling syndrome experienced by female teachers. For this reason, the correlation survey model was used in the research. Female teachers living in Istanbul were selected with the appropriate sampling method due to the Covid 19 outbreak. "The Paternal Leadership Behaviors Scale of School Principals" and "Glass Ceiling Syndrome Scale for Female Teachers" were applied to 358 female teachers. Applied t-test, correlation, ANOVA, and regression analysis. As a result of statistical analysis, it saw that the benevolent, moral, authoritarian, and exploitative leadership behaviors perceived by teachers significantly predicted the perceptions of glass ceiling syndrome. Although benevolent, moral, authoritarian, exploitative paternalistic leadership behaviors mainly indicated teachers' perception of the glass ceiling, they were even low. Especially authoritarian and exploitative paternalistic leadership behaviors explained 5\% of the total variance in teachers' perception of the glass ceiling syndrome.

Keywords: glass ceiling syndrome, paternalistic leadership, female teachers, correlation survey model
\end{abstract}

\section{Introduction}

Women are exposed to barriers in their work-life that are not clearly stated. The rise of female employees has been hindered or slowed down due to the obstacles they have faced throughout their careers. At the same time, these obstacles have been damaged into their sense of accomplishment. Women employees cannot see mentor female managers in their work-life so they cannot even gather their courage and take the first step. Therefore, these obstacles affect all women workers.

Although these invisible barriers occur in many sectors, they are common in the education sector. While the number of female teachers is high in the education sector of many countries, the number of female principals is low. Coleman (2002) stated that female teachers are not included in managerial positions apart from preschool groups. As the age of students increases, the number of women in administration decreases. According to female teachers, teaching is more attractive than management. Therefore, they avoid being managers (Shakeshaft, 2000). On the other hand, what are the other reasons that they are not inclined to managerial duties?

\section{Glass Ceiling Syndrome}

Invisible barriers nurtured by attitudes and organizational prejudices that prevent women from achieving senior management positions are called glass ceiling syndrome (Wirth, 2001). 
PROBLEMS

OF EDUCATION IN THE $21^{\text {st }}$ CENTURY Vol. 79, No. 5, 2021

768

These barriers are examined under three headings as individual, organizational, and social barriers. Individual barriers are multiple roles and personal preferences. Organizational barriers are organizational culture and organizational policies, the queen bee syndrome, lack of mentors, and the inability to participate in social networks. Lastly, social barriers are occupational discrimination and stereotypes expressing prejudices against female managers (Janus, 2008; Lemon, 2003; Wrigley, 2002).

Jain and Mukherji (2010) stated that the glass ceiling concept has two types: vertical and horizontal. The vertical glass ceiling refers to the obstacles that female employees face in the hierarchy within the organization. The horizontal glass ceiling illustrates the difficulties faced by women, especially in male-dominated organizations, as they need to adapt their behavior to the existing male-dominated cultural structure of the organization.

Li (2014) emphasized that the emergence of the glass ceiling syndrome went through a multi-faceted process and explained that the examples of discrimination listed below could generally be seen as signs that any organization has experienced a glass ceiling experience; Informal recruitment practices not hiring women, education and guidance services that deprive women of services, women are not allowed to enter informal networks, giving men more rights in career planning. However, women have similar job descriptions and titles; their wages are lower than men's, lacking adequate career and personal development opportunities.

Glass ceiling syndrome is a global issue. The European Institute for Gender Equality (EIGE) presents data on how European countries achieve gender equality. Calculated data according to variables are related to inequality and violence regarding women. According to the EIGE report (2019), Sweden was the country with the highest gender equality in Europe, with 83.6 points out of 100. Denmark, France, and Finland follow Sweden. Greece is at the bottom of the list. The average score of the EU in the index is 67.4 out of 100 .

The position in Turkey seems worse. According to statistics of TUIK labor (2018), while the whole 78.5 of men in the group of 15-64 years joining the labor, this rate is only $38 \%$ in women. In Turkey, women deputy takes parts of to 17.4 in the parliament, and this rate remains under the World average, which is about 23.4\%. Currently, only 104 of 594 cabinet deputies in the parliament are women; still, there are only two women ministers in the present cabinet. The women cannot find a place in higher-up positions such as management on equal terms with men. According to the World Bank Entrepreneurship Survey (2018) search, there are senior women managers in only 5.4 companies. Only $21.9 \%$ of full-time working are women. Finally, according to the World Economic Forum's Global Gender Gap Report (2018), Turkey places in the 130 line of the 149 countries in terms of gender equality. The situation is no different in the Ministry of National Education. In ministry, 1274 of 1299 managers serve provincial, national education, provincial deputy, and district national education directors (Ministry of Education, 2020). Many glass ceilings prevent women from being promoted to senior executive positions. However, the obstacles in educational administration can be summarized as follows: openly and covert discrimination, institutional restrictions, the theory of women's socialization, and the dominance of male culture (Bridge, 2003).

\section{Paternalistic Leadership}

While talking about the glass ceiling syndrome, we should not ignore organizational culture and policies. In this direction, different leadership styles can have significant effects on female employees' work life. Paternalistic leadership is one of the leadership styles and defines as a benevolent dictatorship in Western society. On the other hand, it describes a strong discipline and a leadership style in which an interest specific to fathers feel in collective communities (Aycan, 2001). Researchers have classified paternalistic leadership as authoritarian, benevolent, and moral (Farh and Cheng (2000). Pellegrini et al. (2010) and Aycan (2006) have sized them as 
benevolent and exploitative paternalistic leadership. In the benevolent dimension, a paternalistic leader protects his subordinates and deals with their work problems or personal life.

On the other hand, it makes you feel who the boss is by always showing a solid authority attitude (Cheng et al., 2004). In the authoritarian dimension, the leader has a high image. It has absolute power and tight control over its subordinates (Cheng, 1995). A moral paternalistic leader abides by the rules accepted by society and shows as an example by the environment. It uses his authority and power not only for its interests but also for community benefit (Westwood, 1997). The reason for the interest of the exploitative leader to its subordinates is to gain their love and draw and then expand its power in return for their positive approach (Hayek et al., 2010).

Researchers have explored paternalistic leadership together with different social science topics. Hao and Lirong (2007) examined the relation between organizational justice and paternalistic leadership and revealed a positive relation between them. Kurt (2013) found a positive relation between paternalistic leadership and creative participation perceptions. Besides, paternalistic leadership increases organizational commitment (Göncü et al., 2014; Mete and Serin, 2015; Rehman and Afsar, 2012; Şendoğdu and Erdirençelebi, 2014) and increases performance (Hatipoğlu et al., 2019).

According to The Economist (2020), the OECD average is $60 \%$ in the glass-ceiling index. South Korea, Japan, and Turkey are at the top and far below the list average. This index shows women's various rights such as participation in higher education, labor force participation, childcare costs, parental leave, legal rights, female senior and middle management ratios, women's representation in parliament, and the gender pay gap. On the other hand, many western and Scandinavian countries where the paternalistic leadership style is not adopted are above the OECD average. Countries with paternalistic leadership seem to fail when it comes to the rights of women workers. In other words, paternalistic leadership behaviors that are dominant in traditional collectivist cultures may not provide women with the necessary opportunities and conditions in the working environment. There is no research on the relation between paternalistic leadership and the rights and freedoms of female employees. In this sense, it has been wondered whether there is a relation between paternalistic leadership and glass ceiling syndrome as a new perspective in the literature. Do female teachers working with paternalistic leaders feel the glass ceiling syndrome intensely? The answer to this question is crucial as it may reveal a new variable affecting the glass ceiling syndrome.

Therefore, the primary purpose of the research was;

- To reveal the relation between the glass ceiling syndrome perceived by female teachers and the paternalistic leadership behaviors of the school principal. In addition, it was aimed to determine whether this relation differs significantly according to the demographic variables of female teachers.

The findings are essential in terms of both revealing the existence of a new variable affecting the glass ceiling syndrome and evaluating paternalistic leadership only from the perspective of female teachers.

\section{Research Methodology}

\section{Research Design}

This quantitative study aimed to determine the relation between school principals' paternalistic leadership behaviors and glass ceiling syndrome in the last quarter of 2020. Therefore, the correlation survey model was used in the study. Correlation survey models, which are a type of survey models, are research models that aim to determine the existence and/ or degree of co-variation between two or more variables (Karasar, 2000, p.81). 
PROBLEMS

OF EDUCATION

IN THE $21^{\text {st }}$ CENTURY Vol. 79 , No. 5, 2021

770

\section{Participants}

The research consists of 358 female teachers who were selected with the method of convenience sampling, because participants who are fast and ready to reach are preferred in terms of time and cost (Ackoff, 1953). In the research, a convenience sampling, method was used due to the COVID19 pandemic. Online form links were sent to the participants through the researcher's social networks. Participants included in the study also sent the links to other female teachers working in Istanbul. In this way, a large group was reached. 84.9\% (304) of the female teachers participating in the study worked with a male school principal, 15.1\% (54) of them worked with a female school principal. Participating teachers had different demographic characteristics. These properties are given in Table 1 below.

Table 1

Demographic of Teachers

\begin{tabular}{|c|c|c|c|}
\hline & Groups & $N$ & $\%$ \\
\hline \multirow{4}{*}{ Age } & $22-28$ & 38 & 10.6 \\
\hline & $29-35$ & 119 & 33.2 \\
\hline & $36-45$ & 137 & 38.3 \\
\hline & $>45$ & 64 & 17.9 \\
\hline \multirow{2}{*}{ Marital status } & Single & 73 & 20.4 \\
\hline & Married & 285 & 79.6 \\
\hline \multirow{2}{*}{ School type } & Public schools & 313 & 87.4 \\
\hline & Private schools & 45 & 12.6 \\
\hline \multirow{2}{*}{ Post graduate education status } & None & 299 & 83.5 \\
\hline & Post graduate & 59 & 16.5 \\
\hline \multirow{2}{*}{ Task type } & Teacher & 292 & 81.6 \\
\hline & School Principal & 66 & 18.4 \\
\hline \multirow{9}{*}{ Branch } & English language teacher & 115 & 32.1 \\
\hline & Class teacher & 76 & 21.2 \\
\hline & Math teacher & 21 & 5.9 \\
\hline & Turkish language teacher & 17 & 4.7 \\
\hline & History teacher & 4 & 1.1 \\
\hline & Social Studies teacher & 3 & 0.8 \\
\hline & Pre-school teacher & 35 & 9.8 \\
\hline & Science and Technology teacher & 12 & 3.4 \\
\hline & Others & 75 & 20.9 \\
\hline
\end{tabular}

\section{Measures}

Demographic form and two scales were used in the study. 7-item personal information form to determine demographic characteristics, the "Paternalistic Leadership Behaviors Scale of School Principals" scale with 22 items and the "Glass Ceiling Syndrome Scale for Female Teachers" with 45 items are used.

Paternalistic Leadership Behaviors Scale of School Principals: It was developed by Dağlı and Ağalday (2017). The scale consists of two parts. There are five items on personal 
information in the first section. In the second section, there are 22 items about the paternalistic leadership behaviors of school principals. As a result of the exploratory factor analysis conducted to determine the construct validity of the scale, a structure consisting of 22 items and four factors (benevolent leadership, moral leadership, authoritarian leadership, exploitative leadership) was obtained. Items no 10, 11, 12, 13, 14, 15 and 16 in the scale are reverse coded.

Glass Ceiling Syndrome Scale for Female Teachers: It was developed by Mert (2019). The purpose of the scale is to determine the glass ceiling syndrome perceived by female teachers. The Glass Ceiling Syndrome for Female Teachers scale consists of 45 items. Items no $3,5,32,37,42,43$ and 45 in the scale are reverse coded.

Cronbach's alpha values were used for the reliability of the scales. Reliability values of the Glass Ceiling Syndrome Scale and the research were used respectively .83 and .725. Paternalistic Leadership Behaviors Scale of School Principals and the research were respectively .898 and .497 .

\section{Data Analysis}

Before analyzing the data, kurtosis and skewness values were calculated and given in Table 2 by examining whether the data showed normal distribution or not.

Table 2

Kurtosis and Skewness Values of the Scales

\begin{tabular}{llll}
\hline & $\mathbf{N}$ & Kurtosis & Skewness \\
\hline Glass Ceiling Syndrome Scale & 358 & .07 & -.14 \\
Paternalistic Leadership Scale & 358 & .60 & -.43 \\
Benevolent Leadership & 358 & .07 & -.61 \\
Moral Leadership & 358 & .99 & -.28 \\
Authoritarian Leadership & 358 & -.61 & -.13 \\
Exploitative Leadership & 358 & -.24 & -.22 \\
\hline
\end{tabular}

When the table was examined, it was observed that the data for kurtosis ranged from -.61 to 99 , while the data for skewness ranged from -.61 to -.13, and it was decided that the data showed a normal distribution. The arithmetic mean information of the scales was evaluated according to the given criteria:1.00-1.79 = very low, 1.80-2.59= low, 2.60-3.39 = medium, 3.40-4.19 = high, $4.20-5.00=$ very high.

\section{Research Results}

Comparison of female teachers' perceptions of paternalistic leadership behaviors and glass ceiling syndrome according to school type, post graduate education and marital status variables are given in Table 3. 
Pinar MERT. The relation of paternalistic leadership with glass ceiling syndrome

PROBLEMS

OF EDUCATION

IN THE $21^{\text {st }}$ CENTURY

Vol. 79 , No. 5,2021

Table 3

Female Teachers' Perceptions of Paternalistic Leadership Behaviors and Glass Ceiling Syndrome according to Demographic Variables

\begin{tabular}{|c|c|c|c|c|c|c|c|}
\hline & Independent varia & & $N$ & $M$ & $S D$ & $t$ & $p$ \\
\hline & Public schools & & 313 & 3.28 & .96 & 205 & 041 \\
\hline & Private schools & & 45 & 3.53 & .72 & -2.00 & .044 \\
\hline Benevolent Leadership & None & & 299 & 3.31 & .93 & 03 & 077 \\
\hline & Post graduate & & 59 & 3.31 & .94 & -.00 & 1 \\
\hline & Single & & 73 & 3.24 & .96 & 73 & 162 \\
\hline & Married & & 285 & 3.33 & .93 & -.10 & .400 \\
\hline & & Public schools & 313 & 3.12 & .27 & 210 & 021 \\
\hline $\begin{array}{l}\text { Moral Leadership } \\
\text { Private schools }\end{array}$ & & 45 & 3.01 & .33 & & 2.18 & .034 \\
\hline None & & 299 & 3.11 & .28 & & & \\
\hline Post graduate & & 59 & 3.07 & .27 & 1.18 & .24 & \\
\hline Single & & 73 & 3.05 & .29 & & & \\
\hline & & 285 & 3.12 & .28 & -1.71 & .089 & \\
\hline & & Public schools & 313 & 3.21 & .97 & & 521 \\
\hline $\begin{array}{l}\text { Authoritarian Leadership } \\
\text { Private schools }\end{array}$ & & 45 & 3.31 & 1.01 & & -.04 & .521 \\
\hline None & & 299 & 3.24 & 1 & & & \\
\hline Post graduate & & 59 & 3.15 & .84 & .61 & .543 & \\
\hline $\begin{array}{l}\text { Single } \\
\text { Married }\end{array}$ & & 73 & 3.28 & .87 & & & \\
\hline & & 285 & 3.21 & 1 & .64 & .521 & \\
\hline & & Public schools & 313 & 3.33 & .91 & -87 & 383 \\
\hline $\begin{array}{l}\text { Explottative Leadersnip } \\
\text { Private schools }\end{array}$ & & 45 & 3.45 & .81 & & . & .000 \\
\hline None & & 299 & 3.33 & .91 & -39 & 698 & \\
\hline Post graduate & & 59 & 3.38 & .81 & -.39 & .098 & \\
\hline $\begin{array}{l}\text { Single } \\
\text { Married }\end{array}$ & & 73 & 3.39 & .82 & & & \\
\hline & & 285 & 3.33 & .92 & .49 & .020 & \\
\hline & & Public schools & 313 & 3.23 & .33 & -184 & 066 \\
\hline $\begin{array}{l}\text { Paternalistic Leadership } \\
\text { Private schools }\end{array}$ & & 45 & 3.32 & .31 & & -1.04 & .000 \\
\hline None & & 299 & 3.24 & .32 & 39 & 696 & \\
\hline Post graduate & & 59 & 3.22 & .35 & .09 & .090 & \\
\hline $\begin{array}{l}\text { Single } \\
\text { Married }\end{array}$ & & 73 & 3.21 & .33 & & & \\
\hline & & 285 & 3.25 & .33 & .39 & .696 & \\
\hline & & Public schools & 313 & 3.36 & .28 & 205 & 011 \\
\hline $\begin{array}{l}\text { Glass Ceiling Syndrome } \\
\text { Private schools }\end{array}$ & & 45 & 3.27 & .30 & & 2.05 & .041 \\
\hline None & & 299 & 3.33 & .28 & & & \\
\hline Post graduate & & 59 & 3.42 & .29 & -2.08 & .039 & \\
\hline Single & & 73 & 3.31 & .30 & & & \\
\hline Thanted & & 285 & 3.35 & .28 & -2.08 & .039 & \\
\hline
\end{tabular}

As can be seen in Table 2, there is no significant difference in paternalistic leadership between teachers' perceptions according to the school type, variable they work with. In its 
subgroups, a significant difference was found between the benevolent leadership and the school type, they work for. Private school teachers have a higher perception of benevolence than those in public schools and it shows low effect $(d=0.02)$. A significant difference has also been found between moral leadership and the school type they work for. Moral leadership perceptions were found to be higher in public schools and the calculated effect size $(d)$ shows that it is low $(d=$ 0.02). A significant difference was detected in the perception of glass ceiling syndrome, and it shows high effect $(d=1.01)$. According to this, teachers' perception of glass ceiling syndrome $(M=3.36)$ in public schools is significantly higher than the perception of teachers working in private schools $(M=3.27)$.

According to the post graduate education variable, it was determined that there was no significant difference in teachers' perceptions of school principals' paternalistic leadership behaviors and its subgroups. There is a significant difference between teachers' post graduate education status and perception of glass ceiling syndrome. Postgraduate teachers $(M=3.42)$ have a higher perception of glass ceiling syndrome than those who do not $(M=3.33)$.

No significant difference was found between Paternalistic leadership and its subgroups according to marital status. A significant difference was found between the perception of glass ceiling syndrome and marital status. Perceptions of glass ceiling syndrome were found to be higher in married teachers $(M=3.35)$ than single teachers. The calculated effect size $(d=0.01)$ shows that it is low. The ANOVA results on perceptions of female teachers on glass ceiling syndrome by age are given in Table 4 .

\section{Table 4}

ANOVA Results on Perceptions of Female Teachers on Glass Ceiling Syndrome by Age

\begin{tabular}{|c|c|c|c|c|c|c|c|c|c|c|}
\hline & Age & $N$ & $M$ & $S D$ & Source of Variance & $\begin{array}{l}\text { Sum of } \\
\text { Squares }\end{array}$ & $d f$ & $\begin{array}{l}\text { Mean } \\
\text { Square }\end{array}$ & $F$ & $p$ \\
\hline \multirow{5}{*}{ 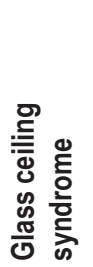 } & A-22-28 & 38 & 3.29 & .25 & Between Groups & .98 & 3 & .33 & 4.22 & \multirow{2}{*}{$\begin{array}{l}.006 \\
C>D\end{array}$} \\
\hline & B-29-35 & 119 & 3.35 & .26 & Within Groups & 27.40 & 354 & .08 & & \\
\hline & C-36-45 & 137 & 3.40 & .29 & Total & 28.38 & 357 & & & \\
\hline & $\mathrm{D}->45$ & 64 & 3.26 & .29 & & & & & & \\
\hline & Total & 358 & 3.35 & .28 & & & & & $* p<$ & \\
\hline
\end{tabular}

Since there is no significant difference between paternalistic leadership and its sub-dimensions, it is not included in the table.

Note: $M=$ Mean, $S D=$ Standard Deviation, $d f=$ Degree of Freedom

When looking at the perception of glass ceiling syndrome by age, a significant difference was found between the ages of 36-45 and over $45(p<.05)$. It was determined that teachers between the ages of 36-45 $(M=3.40)$ had a higher perception of glass ceiling syndrome than teachers over 45 years old. There was no significant difference in age, paternalistic leadership, and its subgroups. The results of the correlation analysis between paternalistic leadership behaviors and its subgroups and Glass Ceiling Syndrome are given in Table 5. 
Pinar MERT. The relation of paternalistic leadership with glass ceiling syndrome

PROBLEMS

OF EDUCATION IN THE $21^{\text {st }}$ CENTURY Vol. 79 , No. 5, 2021

Table 5

The Correlation Analysis between Paternalistic Leadership and Its Subgroups and Glass Ceiling Syndrome

\begin{tabular}{|c|c|c|}
\hline & & Perception of Glass Ceiling Syndrome \\
\hline \multirow{3}{*}{ Benevolent Leadership } & $r$ & $-.14^{*}$ \\
\hline & $p$ & .01 \\
\hline & $N$ & 358 \\
\hline \multirow{3}{*}{ Moral Leadership } & $r$ & $-.12^{*}$ \\
\hline & $p$ & .03 \\
\hline & $N$ & 358 \\
\hline \multirow{3}{*}{ Authoritarian Leadership } & $r$ & $.23^{* *}$ \\
\hline & $p$ & .00 \\
\hline & $N$ & 358 \\
\hline \multirow{3}{*}{ Exploitative Leadership } & $r$ & $.24^{* *}$ \\
\hline & $p$ & .00 \\
\hline & $N$ & 358 \\
\hline \multirow{3}{*}{ Paternalistic Leadership Total } & $r$ & -.01 \\
\hline & $p$ & .92 \\
\hline & $N$ & 358 \\
\hline
\end{tabular}

Note: ${ }^{*} p<.05,{ }^{* *} p<.001$

According to the correlation analysis given in the table, teachers' perceptions of glass ceiling syndrome and benevolent and moral leadership perceptions were negatively and very low $(p<.05)$; There is a positive and low-level significant relation between authoritarian and exploitative leadership and perceptions of glass ceiling syndrome. $(p<.01)$. The regression results of paternalistic leadership behaviors and its subgroups and glass ceiling syndrome are given in Table 6.

\section{Table 6}

Regression Results of Paternalistic Leadership Behaviors and its Subgroups and Glass Ceiling Syndrome

\begin{tabular}{|c|c|c|c|c|c|c|}
\hline Independent variable & Dependent variable & $B$ & SE & B & $t$ & $p$ \\
\hline \multirow{2}{*}{$\begin{array}{l}\text { Benevolent } \\
\text { Leadership }\end{array}$} & \multirow{2}{*}{$\begin{array}{l}\text { Perception of Glass Ceiling } \\
\text { Syndrome }\end{array}$} & 3.48 & .06 & & 63.65 & $<0.001$ \\
\hline & & -.04 & .02 & -.14 & -2.58 & .01 \\
\hline \multicolumn{7}{|c|}{$r=.136 ; r^{2}=.018 ; F=6.66 ; p<.01$} \\
\hline \multirow{2}{*}{ Moral Leadership } & \multirow{2}{*}{$\begin{array}{l}\text { Perception of Glass Ceiling } \\
\text { Syndrome }\end{array}$} & 3.71 & .16 & & 22.68 & $<0.001$ \\
\hline & & -.12 & .05 & -.12 & -2.25 & .03 \\
\hline
\end{tabular}




\begin{tabular}{|c|c|c|c|c|c|c|}
\hline Independent variable & Dependent variable & $B$ & $S E$ & B & $t$ & $p$ \\
\hline \multirow{2}{*}{$\begin{array}{l}\text { Authoritarian } \\
\text { Leadership }\end{array}$} & \multirow{2}{*}{$\begin{array}{l}\text { Perception of Glass Ceiling } \\
\text { Syndrome }\end{array}$} & 3.13 & .05 & & 62.56 & $<0.001$ \\
\hline & & .07 & .02 & .23 & 4.5 & $<0.001$ \\
\hline \multicolumn{7}{|c|}{$r=.232 ; r^{2}=.054 ; F=20.23 ; p<.01$} \\
\hline \multirow{2}{*}{$\begin{array}{l}\text { Exploitative } \\
\text { Leadership }\end{array}$} & \multirow{2}{*}{$\begin{array}{l}\text { Perception of Glass Ceiling } \\
\text { Syndrome }\end{array}$} & 3.09 & .06 & & 55.29 & $<0.001$ \\
\hline & & .08 & .02 & .24 & 4.7 & $<0.001$ \\
\hline \multicolumn{7}{|c|}{$r=.242 ; r^{2}=.058 ; F=22.05 ; p<.01$} \\
\hline \multirow{2}{*}{$\begin{array}{l}\text { Paternalistic } \\
\text { Leadership Total }\end{array}$} & \multirow{2}{*}{$\begin{array}{l}\text { Perception of Glass Ceiling } \\
\text { Syndrome }\end{array}$} & 3.36 & .15 & & 22.63 & $<0.001$ \\
\hline & & -.01 & .05 & -.01 & -.11 & .92 \\
\hline
\end{tabular}

$r=.006 ; r^{2}=.000 ; F=.011 ; p>.05$

The regression analysis given in the table shows that the benevolent, moral, authoritarian, and exploitative leadership behaviors perceived by teachers significantly predict the perceptions of glass ceiling syndrome. Although benevolent, moral, authoritarian, exploitative paternalistic leadership behavior predicts teachers' perception of the glass ceiling syndrome mainly, they are low. Especially authoritarian and exploitative paternalistic leadership behaviors explain 5\% of the total variance in teachers' perception of the glass ceiling syndrome.

\section{Discussion}

This research is based on the interrelation of glass ceiling syndrome and paternalistic leadership. In this research, no significant difference was found between the paternalistic leadership perceptions of teachers and the school type, they work in. It was found a significant difference between benevolent and moral paternalistic leadership, even low. There is no other research to compare paternalistic leadership perceptions of female teachers working in private schools and public schools in Turkey. Therefore, this result is important. On the other hand, a high level of significant difference was found between the teachers' school type, and their perception of the glass ceiling syndrome. According to this, public school teachers' perception of glass ceiling syndrome is higher than that of private school teachers. Mert and Levent (2020) also revealed that female teachers working in public schools feel the glass ceiling syndrome more. Female teachers working in private schools see more positively themselves about being a manager. This result is very striking; education administrators and lawmakers should review what they are doing wrong in public schools of Turkey.

It was found no significant difference in school principals' perceptions of paternalistic leadership behaviors according to post graduate education status of female teachers. Similarly, Dağlı and Ağalday (2018), Özgenel and Dursun (2020) Cheng et al., (2004) and Pellegrini et al., (2010) found that having a post graduate education does not make a significant difference in the perceptions of paternalistic leadership behavior. However, Cerit, et al. (2011) found that as teachers' education levels, asking principals to be paternalistic leaders decreased. Although different results found revealed that having a predominantly post graduate education did not differentiate the paternalistic leadership perceptions of teachers. This situation is due to the large power distance in Turkey. Teachers may choose to be guided by the principals in the school.

Contrary to the studies of Mert and Levent (2020), Y1lmaz (2013), and Güney (2019), this study found a significant difference between teachers' post graduate education status and their perception of the glass ceiling syndrome. The perception of the glass ceiling syndrome 
PROBLEMS

OF EDUCATION IN THE $21^{\text {st }}$ CENTURY Vol. 79, No. 5, 2021

776

of female teachers with post graduate education is higher than female teachers with no post graduate education (Atan 2011; Bodur, 2017). We can explain the reasons for this situation in two different ways. Firstly, female teachers with master's degrees may know and recognize the factors that make up the glass ceiling syndrome. Secondly, female teachers with master's degrees may have made more attempts to become managers than female teachers with no master's degree, and as a result, they may have hit a glass ceiling.

It was found no significant difference between the female teachers' age and the perceptions of school principals' paternalistic leadership behaviors (Bilici, 2017; Cesur, 2015 and Fettahlıoğlu et al., 2018). Taşliyan et al., (2017), on the other hand, revealed that as the age increases, female teachers' school principals perceive more paternalistic. Studies show that the age variable does not always affect the paternalistic leadership perceptions of employees. Güney (2019) revealed no significant difference between the ages of female teachers and their perceptions of glass ceiling syndrome. In this study, perceptions of glass ceiling syndrome among women teachers aged 36-45 and over 45 were higher. Similarly, Atan (2011) revealed that female teachers aged 51 and over about the glass ceiling are higher. This situation may be that female teachers of a certain age and experience can diagnose the problems they experience and call them glass ceiling syndrome, or it may reflect the troubles and difficulties accumulated over many years.

According to the marital status of female teachers, it determined that there was no significant difference in perceptions of paternalistic leadership behaviors of school principals. This result is consistent with other studies (Dağlı and Ağalday, 2018; Fettahlıoğlu et al., 2018; Gürcan, 2018 and Saylık, 2017). Taşliyan et al. (2017) found that single employees perceive their managers as paternalistic than married employees. Generally, studies have revealed that marital status does not differentiate teachers' paternalistic leadership perceptions. Even if female teachers are married or single, they perceive the paternalistic leadership skills of school principals as similar. In this study, married female teachers perceive glass ceiling syndrome more than singles. According to Mert and Levent (2019), female teachers' perceptions of glass ceiling syndrome differ from their marital status. Married female teachers are more likely to perceive glass ceiling syndrome than single female teachers due to family responsibilities. However, Orbay (2018) and Güney (2019) found that marital status did not differ in female teachers' perceptions of glass ceiling syndrome. It is not surprising that the glass ceiling syndrome varies according to the marital status of female teachers. It is because in Turkish society, women have more responsibilities related to the home than men. Because of the fewer working hours of the teaching profession, it is seen as an ideal job for women in Turkey. Therefore, female teachers, especially married female teachers, avoid being managers not to give up their "ideal" working hours.

There is a negative and very low relation between the perceptions of glass ceiling syndrome and the perceptions of benevolent and moral leadership of female teachers. There is a positive and low-level significant relation between the perceptions of authoritarian and exploitative leadership and glass ceiling syndrome. In addition, the benevolent, moral, authoritarian, and exploitative leadership behaviors perceived by female teachers significantly predicted the perception of glass ceiling syndrome, even low. Especially authoritarian and exploitative paternalistic leadership behaviors explain $5 \%$ of the total variance in teachers' perception of the glass ceiling syndrome. Therefore, it is not unreasonable to think that paternalistic leadership, which is dominant in paternalistic cultures, is a type of leadership that can come to mind when explaining the reasons for the glass ceiling syndrome. 


\section{Conclusions}

The variables that cause women to experience glass ceiling syndrome can be various. Since female teachers working in schools work in close contact with school principals, they are influenced by the attitudes and styles of their leaders. Therefore, it is essential to have school principals with leadership styles that support the careers of female teachers. In this sense, it is vital to determine which leadership styles existing in the literature are friendly to female teachers' careers and hostile. According to the results of this research, paternalistic leadership seems to have failed in the leadership of female teachers.

Female teachers need different leadership behavior apart from paternalistic leadership to create a career plan for themselves and overcome these career barriers. Which leadership style should be dominant may also be the main idea of the future research study. In addition, the results of this study are limited to the data obtained from the sample of the study. Therefore, to generalize the research results, it may be suggested rework with different sample groups (like other countries where paternalistic leadership is dominant) or larger groups. Also, leadership types that are dominant in countries with large power distance and leadership types in countries with narrow power distance can be examined in the context of glass ceiling syndrome. It should constitute a map of leadership types that are female manager-friendly in a global sense.

\section{References}

Ackoff, R. L. (1953). The Design of Social Research. University of Chicago Press.

Atan, E. (2011). İlköğretim okullarında görev yapan kadın okul yöneticilerinin "cam Tavan’a ilişkin algılarının incelenmesi (Yüksek Lisans Tezi) [Investigation of "glass ceiling painting algorithms" of female school principals working in primary schools (Master's Thesis)]. Marmara University, İstanbul.

Aycan, Z. (2001). Human resource management in Turkey: Current issues and future challenges. International Journal of Manpower, 22(3), 252-260.

Aycan, Z. (2006). Paternalism: Towards conceptual refinement and operationalizations. In U. Kim, K. S. Yang, \& K. K. Hwang (Eds.), In Indigenous and cultural psychology (pp. 445-466). Springer Science \& Business Media.

Bilici, F. (2017). Tükenmişlik, işe bağlllık, işten ayrılma, babacan liderlikve bir araştırma (Yayınlanmamış Yüksek Lisans Tezi) [Burnout, commitment, quitting, paternalistic leadership and research (Unpublished master's thesis)]. Arel University.

Bodur, E. (2017). İlköğretimde görev yapan kadın öğretmenlerin karşılaştıkları cam tavan en-geller ile tükenmişlik düzeyleri arasındaki ilişki (Yüksek Lisans Tezi) [The relation between glass ceiling obstacles faced by female teachers in primary education and their burnout levels (Master's Thesis)]. Yüzüncü Yil University.

Cerit, Y., Özdemir, T., \& Akgün, N. (2011). Sınıf öğretmenlerinin okul müdürlerinin paternalist liderlik davranışları sergilemelerini istemeye yönelik görüşlerinin bazı demografik değişkenler açısından incelenmesi [ Clasroom teachers' opinions toward primary school principal fulfillment of paternalistic leadership behaviours in terms of some demographic vairables ]. Journal of AIBUU Education Faculty, 11(1), 87-99.

Cheng, B. S. (1995). Paternalistic authority and leadership: A case study of a Taiwanese CEO. Bulletin of the Institute of Ethnology Academic Sinica, 79(3), 119-173

Cheng, B. S., Chou, L. F., Wu, T. Y., Huang, M. P., \& Farh, J. L. (2004). Paternalistic leadership and subordinate responses: Establishing a leadership model in Chinese organizations. Asian Journal of Social Psychology, 7(1), 89-117.

Coleman, M. (2002). Women as Headteachers: Striking a balance. Trentham Books.

Dağlı, A., \& Ağalday, B. (2017). Developing a headmasters' paternalistic leadership behaviours scale in Turkey. Journal of Education and Practice, 8(30), 190-200. https://www.iiste.org/Journals/index. php/JEP/article/view/39293/40400 
Pinar MERT. The relation of paternalistic leadership with glass ceiling syndrome

PROBLEMS

OF EDUCATION IN THE $21^{\text {st }}$ CENTURY Vol. 79, No. 5, 2021

778

Dağlı, A., \& Ağalday B. (2018). Okul müdürlerinin paternalist liderlik davranışlarının incelenmesi [Analysing headmasters' paternalistic leadership behaviours]. Electronic Journal of Social Sciences, 17(66), 518-534.

EIGE. (2019). Gender equality index 2019 index score (2019) / EU-28. https://eige.europa.eu/genderequality-index/2019

Farh, J. L., \& Cheng, B. S. (2000). A Cultural analysis of paternalistic leadership in Chinese organizations. J. T. Li, A. S. Tsui, \& E. Weldon, (Eds), In management and organizations in the Chinese context (pp. 85-127). Macmillan.

Fettahlığlu, Ö. O., Akdoğan, Z., \& Özay, E. (2018). Paternalist liderlik tarzının örgütsel özdeşleşme üzerindeki etkisi [The effect of the paternalist leadership style on organizational identification]. Journal of Social, Humanities and Administrative Sciences, 4(9), 36-51.

Göncü, A., Aycan, Z., \& Johnson, R. E. (2014). Effects of paternalistic and transformational leadership on follower outcomes. International Journal of Management and Business, 5(1), 36-58.

Güney, H. B. (2019). Ortaokul ögretmenlerinin algılarına göre okul müdürlerinin liderlik stilleri ile kadın ögretmenlerin karşılaştıkları cam tavan engelleri (Yüksek Lisans Tezi) [According to the perceptions of middle school teachers, the leadership styles of school principals and the glass ceiling obstacles faced by female teachers (Unpublished master's thesis)]. Dokuz Eylül University.

Gürcan, N. (2018). Türk kültüründe paternalist liderlik davranışlarının izleyenlerin duygusal bağlılıkları üzerindeki etkisi: Y kuşağına yönelik bir araştırma (Yayımlanmamış Yüksek Lisans Tezi) [The effect of paternalist leadership behaviours on the emotional commitment of the followers in Turkish culture: A study for the generation Y (Unpublished master's thesis)]. Dokuz Eylül University.

Hao, Z., \& Lirong, L. (2007). Relationship between paternalistic leadership and organizational justice. Acta Psychologica Sinica, 39(5), 909-917

Hatipoğlu, Z., Akduman, G., \& Demir, B. (2019). Babacan liderlik tarzının çalışan görev performansı ve duygusal bağlılık üzerindeki etkisi [The effect of paternalistic leadership style on employee task performance and emotional commitment]. Journal of Business Research, 11(1), 279-292. https://doi.org/10.20491/isarder.2019.599

Hayek, M., Novicevic, M. M., Humphreys, J. \& Jones, N. (2010). Ending the denial of slavery in management history: Paternalistic leadership of Joseph Emory Davis. Journal of Management History, 16(3), 367-379. https://doi.org/10.1108/17511341011051252

Jain, N. \& Mukherji, S. (2010). The perception of "Glass Ceiling" in Indian organizations: An exploratory study. South Asian Journal of Management, 17(1), 23-42.

Janus, M. J. (2008). Gender Roles, Leadership and Public Relations. A Thesis Presented to The Faculty of The Graduate School at the University of Missori- Columbia, Master of Art.

Karasar, N. (2000). Preparing reports in research (10th Edition). Nobel.

Kirişçi, G. (2018). Eğitim Yöneticilerinin Cam Tavan Sendromuna İlişkin Görüşleri. (Yüksek Lisans Tezi) [Education Managers' Views on Glass Ceiling Syndrome Unpublished master's thesis)]. Kahramanmaraş Sütçü İmam University.

Kurt, İ. (2013). Paternalist liderlik ile çalışanların işlerine yaratıcı katılım algıları arasındak ilişkiyi araştırmaya yönelik bir çalışma [A research study on the relation between paternalistic leadership and employee creative work involvement perceptions]. Journal of Social and Humanities, 5(1), 321-330. https://dergipark.org.tr/tr/download/article-file/117364

Lemons, M. A. (2003). Contextual and cognitive determinants of procedural justice perceptions in promotion barriers for women. Sex Roles, 49(5/6), 247-250.

Li, P. (2014). Recent developments hitting the ceiling: An examination of barriers to success for Asian American women. Berkeley Journal of Gender, Law \& Justice, 29(1), 140-167.

Mert, P. (2019). Kadın öğretmenlerin yönetici olmaları önündeki engellerin cam tavan sendromu bağlamında incelenmesi (Doktora tezi) [Examining the obstacles for female teachers to become managers in the context of glass ceiling syndrome (Doctoral Dissertation)]. Istanbul Sabahattin Zaim University.

Mert, P., \& Levent, A. F. (2020). Female teachers' problem to be the manager: Glass Ceiling Syndrome in Turkey. International Journal of Eurasian Education and Culture, 10(5), 1547-1587.

Mete, Y. A., \& Serin, H. (2015). Okul yöneticilerinin babacan liderlik davranışı ile öğretmenlerin örgütsel vatandaşlık ve örgütsel sinizim davranışları arasındaki ilişki [Relation between school administrators' paternalist leadership behaviours and teachers' organizational cynicism behaviours]. Journal of Hasan Ali Yücel Education Faculty, 12(2), 147-159. 
Ministry of Education. (2020). Formal Education 2019-2020 Statistics. http://sgb.meb.gov.tr/www/millegitim-istatistikleri-orgun-egitim-2018-2019/icerik/361

Orbay, I. (2018). Ortaokul yöneticilerinin cam tavan sendromuna ilişkin algılarının demografik değişkenlere göre farklılaşma durumunun incelenmesi (Yayımlanmamış yüksek lisans tezi) [The perspectives of secondary school principals on glass ceiling syndrome and analysis of their relations with different demographic variables (Unpublished master's thesis)]. İstanbul Kültür University.

Özgenel, M., \& Dursun, İ. E. (2020). Okul müdürlerinin paternalist liderlik davranışlarının okul kültürüne etkisi [The effects of school principals' paternalistic leadership behaviours on school culture]. Journal of Social, Human and Administrative Sciences, 3(4), 284-302.

Pellegrini, E. K., Scandura, T. A., \& Jayaraman, V. (2010). Cross-cultural generalizability of paternalistic leadership: An expansion of leader-member exchange theory. Group \& Organization Management, 35(4), 391-420.

Rehman, M., \& Afsar, B. (2012). The impact of paternalistic leadership on organization commitment and organization citizenship behaviour. Journal of Business Management and Applied Economics, $5(5), 148-159$.

Saylık, A. (2017). Okul müdürlerinin paternalist (babacan) liderlik davranışları ile Hofstede'nin kültür boyutları arasındaki ilişki (Yayınlanmamış Doktora Tezi) [The relation between school principals' paternalistic leadership behaviour and Hofstede's cultural dimensions (Unpublished doctoral dissertation)]. Ankara University.

Shakeshaft, C. (2000). Women in educational management in the United States. Pergamon Press.

Şendoğdu, A., \& Erdirençelebi, M. (2014). Paternalist liderlik ile örgütsel vatandaşlık davranışı arasındaki ilişkiye yönelik bir araştırma [A study on the relation between paternalist leadership and organizational citizenship behaviour]. The Journal of Social and Economic Research, 14(27), 253-274.

Taşlıyan, M., Çiçeklioğlu, H., \& Bıyıkbeyi, T. (2017). Paternalist Liderlik ve Örgütsel İletişim Arasındaki İlişki: Doğu Akdeniz Bölgesinde Bir Belediye Örneği [The relation between paternalist leadership and organizational communication: An example of a municipality in the Eastern Mediterranean region]. Assam Journal, 4(8), 70-87.

The Economist. (2020). Glass Ceiling Index. https://www.economist.com/graphic-detail/2020/03/04/ iceland-leads-the-way-to-womens-equality-in-the-workplace

Turkey Statistical Institute. (2018). Labor Statistics. http://www.tuik.gov.tr/HbPrint.do?id=27688

Westwood, R. I. (1997). Harmony and patriarchy: Then cultural basis for 'paternalistic headship' among the overseas Chinese. Organization Studies, 18(3), 445-480

Wirth, L. (2001). Breaking through the glass ceiling. Women in management. International Labour Office.

World Economic Forum. (2018). The global gender gap report. http://www3.weforum.org/docs/WEF_ GGGR 2018.pdf

World Economic Forum. (2018). The global competitiveness report http://www3.weforum.org/docs/ GCR2018/05FullReport/TheGlobalCompetitivenessReport2018.pdf

Wrigley, B. J. (2002). Glass ceiling? What glass ceiling? A qualitative study of how women view the glass ceiling in public relations and communications management. Journal of Public Relations Research, 14(1), 27-55.

Yılmaz, T. (2013). Kadın ve Erkek Eğitim Yöneticilerinin Cam Tavan Sendromuna İlişkin Algıları İstanbul İli Örneği (Yayımlanmamış Yüksek Lisans Tezi) [The perceptions of glass ceiling among women and men education directorates Istanbul sample (Unpublished master's thesis)]. Maltepe University. 
Pinar MERT. The relation of paternalistic leadership with glass ceiling syndrome

PROBLEMS

OF EDUCATION

IN THE $21^{\text {st }}$ CENTURY

Vol. 79, No. 5,2021

780

Received: July 17, 2021

Accepted: October 03, 2021

Cite as: Mert, P. (2021). The relation of paternalistic leadership with glass ceiling syndrome. Problems of Education in the 21 $1^{\text {st }}$ Century, 79(5), 767-780. https://doi.org/10.33225/pec/21.79.767

Pinar Mert

PhD, Lecturer, Istanbul Sabahattin Zaim University, Halkalı Merkez, Halkalı, 34303 Küçükçekmece/listanbul, Turkey.

E-mail: binarmert@icloud.com

ORCID: https://orcid.org/0000-0003-3633-7556 